\title{
H19, a Developmentally Regulated Gene, Is Reexpressed in Rat Vascular Smooth Muscle Cells after Injury
}

\author{
Duk-Kyung Kim, Lunan Zhang, Victor J. Dzau, and Richard E. Pratt \\ Division of Cardiovascular Medicine, Falk Cardiovascular Research Center, Stanford University School of Medicine, \\ Stanford, California 94305-5246
}

\begin{abstract}
Vascular smooth muscle cell migration, proliferation, and differentiation are central to blood vessel development. Since neointimal formation after vascular injury may require the reexpression of a smooth muscle developmental sequence, we examined the expression of $\mathrm{H19}$, a developmentally regulated gene, in rat blood vessels. Expression of the $\mathrm{H19}$ gene is associated with the differentiation process that takes place during development of many tissues. Consistent with this, H19 was highly expressed in the 1-d-old rat aorta but was undetectable in the adult. H19 transcripts were only minimally detected in uninjured carotid artery but were abundant at 7 and $14 \mathrm{~d}$ after injury and were localized by in situ hybridization, primarily to the neointima. H19 transcript were undetectable in proliferating neointimal cells in culture but became highly abundant in postconfluent, differentiated neointimal cells. H19 transcripts were only minimally expressed in adult medial smooth muscle cells grown under the identical conditions.

Thus, H19 may play an important role in the normal development and differentiation of the blood vessel and in the phenotypic changes of the smooth muscle cells, which are associated with neointimal lesion formation. The vascular injury model may be a useful system to use in examining the function of $\mathrm{H19}$. (J. Clin. Invest. 1994. 93:355-360.) Key words: restenosis • neointimal smooth muscle cells • development • differentiation • neointimal lesions
\end{abstract}

\section{Introduction}

The pathophysiologic growth of vascular smooth muscle cell (VSMC), ${ }^{1}$ which plays a central role in the development of various vascular diseases such as neointimal development, is accompanied by a switch in phenotype of the cells towards a neonatal or embryonic genetic program (1). Many of the phenotypic markers that are reexpressed in the growing VSMCs are constituents of the contractile apparatus (2), the paracrine growth factors $(3)$, or the extracellular matrix $(3,4)$, and are presumably important to the growth characteristics of the cells.

Address correspondence to Dr. Richard E. Pratt, Falk Cardiovascular Research Center, Stanford University School of Medicine, 300 Pasteur Drive, Stanford, CA 94305-5246.

Received for publication 20 May 1993 and in revised form $16 \mathrm{Au}$ gust 1993.

1. Abbreviations used in this paper: DSF, defined serum-free. VSMC, vascular smooth muscle cell.

J. Clin. Invest.

(C) The American Society for Clinical Investigation, Inc.

$0021-9738 / 94 / 01 / 0355 / 06 \$ 2.00$

Volume 93, January 1994, 355-360
However, the expression of many of these proteins is probably secondary to the primary events that mediate cell growth and differentiation. While genes important in the development and differentiation of skeletal muscle cells have been isolated (5), no genes with similar functions have been identified for vascular VSMC.

H19 is a developmentally regulated gene whose expression peaks during fetal development when tissue differentiation is occurring (6). It is highly expressed in mouse embryonic tissue of endodermal and mesodermal origin and is dramatically downregulated after birth (7). At present, the function of H19 gene is unknown. However, the overexpression of the H19 gene in transgenic mice caused prenatal lethality in the late portion of the gestational period (8). $\mathrm{H} 19$ gene has been independently isolated by several investigators interested in genes activated during myoblast differentiation (Myo $\mathrm{H})(5)$ and during embryonal carcinoma cell differentiation (9). These observations suggest that $\mathrm{H} 19$ has a crucial role in cellular development and differentiation.

The regulation of $\mathrm{H} 19$ gene expression in blood vessel development and neointimal formation is unclear. Han and Liau (10), using differential screening, have isolated a cDNA from a rabbit fetal aortic smooth muscle cell library that exhibits $73 \%$ homology to the human H19 cDNA, which they termed F-31. However, in the rabbit, F-31 does not show the same pattern of expression observed for $\mathrm{H} 19$ in other species. For example, while $\mathrm{H} 19$ is expressed in the heart and skeletal muscle of the adult rat, F-31 is not expressed in the rabbit heart and is only weakly expressed in the rabbit skeletal muscle. Thus, at this point, it is not known if $\mathrm{F}-31$ is the rabbit homologue of $\mathrm{H} 19$ or if it is a closely related gene. However, based on these results, we reasoned that $\mathrm{H} 19$ may be a useful marker to further examine the hypothesis that VSMCs induced to proliferate under pathologic conditions recapitulate ontogeny. In the present study, we demonstrated developmental regulation of $\mathrm{H} 19$ gene in postnatal aortae and its reexpression in the neointima in the injured rat carotid artery. In addition, we observed that the expression of $\mathrm{H} 19$ in cultured vascular smooth muscle cells was dependent on the growth and differentiation state of the cells.

\section{Methods}

Arterial injury model and animals. Male Sprague-Dawley rats (300$350 \mathrm{~g}, 12$ wk old) (Charles River Breeding Laboratories, Cambridge, MA) were anesthetized with the administration of ketamine hydrochloride $(80 \mathrm{mg} / \mathrm{kg})$ (Parke-Davis, Morris Plains, $\mathrm{NJ})$ and xylazine ( 12 $\mathrm{mg} / \mathrm{kg}$ ) (Lloyd Laboratories, Shenandoah, IA). A French arterial embolectomy balloon catheter (no. 2; American Edward Laboratories, Santa Ana, CA ) was introduced into the left common carotid artery via the external carotid artery and passed into the aortic arch. The balloon was inflated sufficiently (filling volume $0.2 \mathrm{ml}$ ) and pulled back slowly into the left common carotid to the entry point. This procedure was repeated two more times. After removal of the catheter the external 
carotid artery was ligated and the wound was closed. The right uninjured carotid artery served as control. Tissues were harvested at the indicated times after injury.

To study developing vessels, aortae were harvested from neonatal rats at various times after birth.

Cell isolation and culture. $14 \mathrm{~d}$ after balloon injury the left (injured) and right (uninjured) carotid arteries were removed for isolation of VSMCs by a modification of the method of Owens et al (11). Vessels were stripped of loose perivascular connective tissues and placed in an enzyme dissociation mixture consisting of Waymouth's M13 752/1 medium (Gibco BRL, Gaithersburg, MD); $1 \mathrm{mg} / \mathrm{ml}$ type 2 collagenase, Biochemical Co., $0.25 \mathrm{mg} / \mathrm{ml}$ elastase, and $1 \mathrm{mg} / \mathrm{ml}$ soybean trypsin inhibitor (each from Worthington Biochemical Co., Freehold, NJ); 2 mg/ml BCA (fraction V; Sigma Chemical Co., St. Louis, MO) at $37^{\circ} \mathrm{C}$ for $10 \mathrm{~min}$. This procedure facilitated dissection of the adventitia, media, and neointima. Under a dissecting microscope, vessels were opened longitudinally. To obtain control medial VSMCs from the uninjured right carotid artery, endothelial cells were first removed by gentle scraping using forceps. Medial tissue was stripped and cut into small pieces. To obtain neointimal VSMCs from the injured left carotid artery, the neointimal layer was first stripped, using fine forceps, and treated as above for the medial VSMCs. The isolation of the neointimal region was confirmed by hematoxylin and eosin staining of stripped vessel (data not shown). The dissected media and neointima were incubated in the same enzyme dissociation mixture (see above) at $37^{\circ} \mathrm{C}$ for $60 \mathrm{~min}$ in a gyratory shaker. Cells were titurated every $30 \mathrm{~min}$. After adding 20\% FBS (Gibco BRL) to inactivate the enzymes, the cell suspension was filtered through a sterile gauze to remove undigested tissue. The cells were centrifuged ( $200 \mathrm{~g}, 5 \mathrm{~min})$ and resuspended in Waymouth's medium supplemented with $10 \% \mathrm{FBS}, 100 \mathrm{mg} / \mathrm{ml}$ penicillin, and $0.1 \mathrm{mg} / \mathrm{ml}$ streptomycin (Gibco BRL) and plated on a 25 $\mathrm{cm}^{2}$ tissue culture flask (Falcon Plastics, Oxnard, CA), with a density of $2-5 \times 10^{3}$ cells $/ \mathrm{cm}^{2}$. The cells were incubated at $37^{\circ} \mathrm{C}$ in a humidified $5 \% \mathrm{CO}^{2}-95 \%$ air atmosphere. The culture medium was changed after 18-24 $\mathrm{h}$ and then routinely changed at $48-72-\mathrm{h}$ intervals thereafter.

Both neointimal and control medial VSMCs stained positively for alpha-smooth muscle actin as determined by immunohistochemistry using a specific mAb (Sigma Chemical Co.).

Cells were routinely passaged at a 1:3 to $1: 5$ ratio and studied between passages 5 and 8. Preconfluent cells were harvested at $60-70 \%$ confluence. Confluent cells were harvested when VSMCs had reached $100 \%$ confluence. At confluence, the cells were made quiescent by incubation for $72 \mathrm{~h}$ in a defined serum-free (DSF) medium containing insulin $\left(5 \times 10^{-7} \mathrm{M}\right)$, transferrin $(5 \mathrm{mg} / \mathrm{ml})$, and ascorbate $(0.2 \mathrm{mM})$. This growth condition maintains VSMCs in a quiescent, noncatabolic differentiated state and promotes the expression of VSMC-specific proteins (11).

RNA isolation. Frozen samples of the aorta and the carotid arteries were homogenized in guanidine isothiocyanate. Total RNA was isolated by centrifugation through a cesium chloride solution (12) and quantitated by UV absorption. For RNA isolation from the injured and control carotid arteries, typically $10-20$ vessels were pooled. The yield of RNA was approximately $5 \mu \mathrm{g}$ per vessel. For RNA isolation from the developing aorta, typically $20-40$ vessels were pooled. Yields of RNA ranged from $\sim 5 \mu \mathrm{g}$ per vessel for the 1-d-old vessel to $20 \mu \mathrm{g}$ per vessel for the adult animals. RNA isolations were repeated at least twice with similar results.

Reverse transcription-polymerase chain reaction (RT-PCR) and probe construction. Based on the homologous nucleotide sequence between the human and mouse H19 cDNA sequence $(6,9)$, two oligonucleotide primers for PCR were prepared (sense; 5'-AGGGCCCACAGTGGACTTGG-3', antisense; 5'-TCACACCGGACCATGTCATGT-3'), which cover 395 base pairs (nucleotide sequence 582-976) of the mouse $\mathrm{H} 19 \mathrm{cDNA}$. After reverse transcription of $100 \mathrm{ng}$ of total RNA by oligo(dT) priming the resulting single stranded cDNA was subjected to PCR using the GeneAmp RNA PCR kit (Perkin-Elmer Cetus, Norwalk, CT). Each PCR cycle consisted of a denaturation step $\left(95^{\circ} \mathrm{C}, 1 \mathrm{~min}\right)$, an annealing step $\left(60^{\circ} \mathrm{C}, 2 \mathrm{~min}\right)$, and an elongation step $\left(72^{\circ} \mathrm{C}, 3 \mathrm{~min}\right)$. The PCR products were resolved on the $1.5 \%$ agarose gel. PCR analysis of each sample was repeated at least three times.

The PCR-amplified fragment was subcloned into pCRII vector (Invitrogen Corp., La Jolla, CA), generating pCRH19-4. Specificity of the PCR amplification was checked by sequencing (data not shown). For Northern blot analysis, the cloned inserts from pCRH19-4 were isolated and radiolabeled with $\left[{ }^{32} \mathrm{P}\right] \mathrm{dCTP}$ by a random primer labeling (Gibco BRL).

Northern blot analysis. $20 \mathrm{mg}$ of total RNA was electrophoresed on $1 \%$ denaturing formaldehyde agarose gel, containing ethidium bromide as described (12). The gels were examined under UV to demonstrate equal loading. RNA samples were transferred onto nylon membrane (Genescreen, New England Nuclear, Boston, MA) and then hybridized to a rat $\mathrm{H} 19 \mathrm{cDNA}$ probe $\left(10^{6} \mathrm{cpm} / \mathrm{ml}\right)$. Filters were washed two times ( 5 min each) in $0.5 \times \mathrm{SSC}(1 \times \mathrm{SSC}=0.15 \mathrm{M} \mathrm{NaCl}, 15 \mathrm{mM}$ sodium citrate), $0.1 \%$ SDS at room temperature, then three times ( 30 min each) in $0.2 \times \mathrm{SSC}, 0.1 \% \mathrm{SDS}$ at $56^{\circ} \mathrm{C}$. Autoradiography was performed for $2 \mathrm{~d}$, using Kodak XAR-5 film with intensifying screens at $-70^{\circ} \mathrm{C}$.

In situ hybridization. $14 \mathrm{~d}$ after balloon injury, rats were anesthetized with ether and perfused at physiological pressure $(110 \mathrm{~mm} \mathrm{Hg})$ through the left ventricle with $100 \mathrm{ml} \mathrm{PBS,} \mathrm{pH} \mathrm{7.2,} \mathrm{followed} \mathrm{by} 80 \mathrm{ml}$ of freshly prepared $4 \%$ paraformaldehyde. After removal of the carotid artery, postfixation was performed with the same fixative as described above at $4^{\circ} \mathrm{C}$ for 4 , h, after which the tissue was embedded in paraffin. Injured and control uninjured vessels were placed side by side in one block. 6- $\mu \mathrm{m}$ sections were cut and placed on 3-amino-propyltriethoxysilane (Sigma Chemical Co.) coated glass slides. ${ }^{35}$ S-labeled antisense and sense complementary RNA were generated as previously described (12) from pCRH19-4, using the Riboprobe Gemini II core system (Promega Corp., Madison, WI). In situ hybridization was performed using the in situ hybridization system (Oncor, Gaithersburg, MD), according to the manufacturer's instructions, using a $10^{6} \mathrm{cpm} / \mathrm{ml}$ probe. After final washing, dehydrated slides were dipped in diluted photographic emulsion (NTB-2, Eastman Kodak Co.), and exposed for 2 wk at $4^{\circ} \mathrm{C}$. The slides were developed and fixed, counterstained with hematoxylin and eosin, examined on a microscope, and photographed.

\section{Results}

The expression of $\mathrm{H} 19$ during ontogeny exhibits tissue specific regulation (5-9). Therefore, we investigated $\mathrm{H} 19$ gene expression during blood vessel development. Using RT-PCR technique, the PCR amplification products were examined after $25,30,35$, or 40 cycles. Little or no amplification product was observed when RNA from adult aorta was used as a template. In contrast, a strong signal was detected when RNA from the 1-d-old pup aorta was used (Fig. $1 A$ ). In order to examine the time course of H19 mRNA expression after birth, Northern blotting analysis was performed (Fig. $1 B$ ). Northern analysis of rat aortic RNA demonstrated the presence of the specific 2.3-kb H19 mRNA transcript. In the developing aorta, H19 mRNA was higher in 1-d-old aorta, then decreased progressively in the 1-wk- and 2-wk-old aorta. H19 mRNA was barely detectable in 12-wk-old adult aorta. Thus, H19 expression is developmentally regulated in the developing vessels of the rat.

Next, we investigated expression of $\mathrm{H} 19$ after vascular injury. Using RT-PCR, RNA from the injured vessels showed a strong signal compared to that of the uninjured vessels (Fig. 2 $A$ ). Northern blot analysis showed that $\mathrm{H} 19$ gene expression was very weak $3 \mathrm{~d}$ after balloon injury but increased progressively over the next $4 \mathrm{~d}$, exhibiting a strong signal at $7 \mathrm{~d}$, and remained at the same intensity $14 \mathrm{~d}$ after vascular injury (Fig. 2 

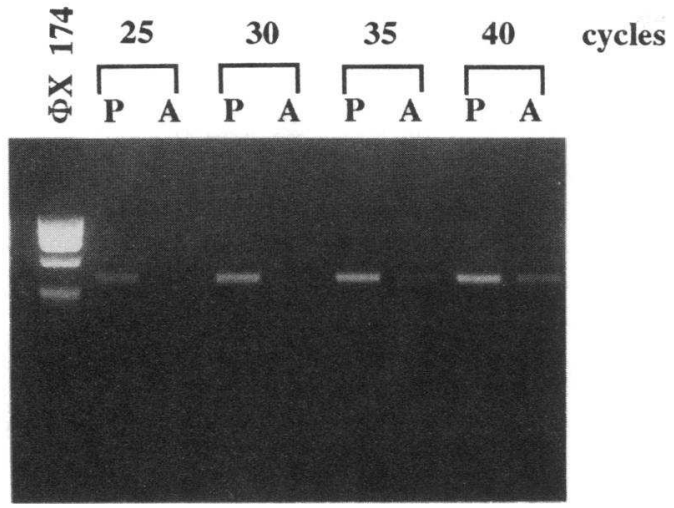

B

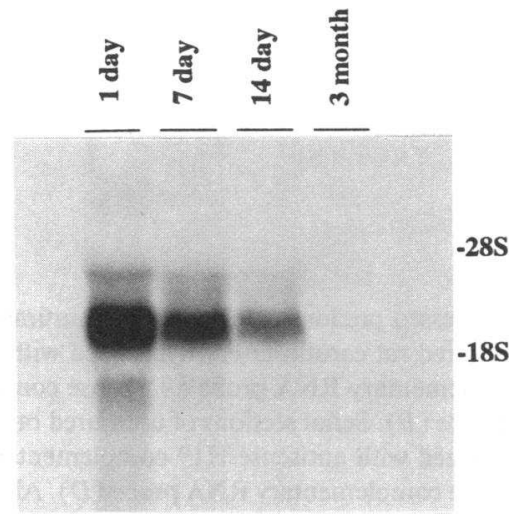

Figure 1. Developmental regulation of $\mathrm{H} 19$ in neonatal rat aortae. Total RNA isolated from rat aorta was analyzed by RT-PCR $(A)$ or Northern blotting $(B)$ for the presence of $\mathrm{H} 19$ mRNA. In $A, 100 \mathrm{ng}$ total RNA isolated from 1-d-old pups $(P)$ or 3-mo-old adult rats $(A)$ was reverse transcribed and amplified for $25,30,35$, or 40 cycles and the amplification products analyzed by agarose gel electrophoresis. In $B, 20 \mu \mathrm{g}$ total RNA from 1-d, 7-d, 14-d, or 3-mo-old rats was analyzed by Northern blotting.

$B)$. In contrast, control uninjured right carotid artery contained little, if any, $\mathrm{H} 19$ mRNA.

To localize H19 mRNA expression within the vessel wall, we performed in situ hybridization analysis. Emulsion autoradiography of sections hybridized to a ${ }^{35} \mathrm{~S}$-labeled rat $\mathrm{H} 19$ antisense RNA probe demonstrated that hybridization signal was abundant in the neointima, but low or absent in the underlying media, $14 \mathrm{~d}$ after balloon injury (Fig. $3 \mathrm{~A}$ ) or in the media of uninjured vessel (Fig. $3 C$ ). The control sense probe showed only rare grains indicating minimal nonspecific binding (Fig. 3 $B$ and $D$ ).

Since $\mathrm{H} 19$ gene is reexpressed after vascular injury, it was of interest to examine whether the expression of this gene could be regulated in cultured neointimal cells. We cultured vascular smooth muscle cells from the neointima of a carotid artery that was balloon injured $14 \mathrm{~d}$ earlier. Control medial VSMCs were isolated from uninjured carotid arteries. In subconfluent conditions, the two cultures appeared morphologically similar and both stained positively for alpha-smooth muscle actin (Fig. $4 \mathrm{~A}$ and $B$ ). At confluence, the cultured medial VSMC exhibited the typical morphology of adult VSMC showing multilayered, spindle-shaped "hill and valley" appearance (Fig. $4 C$ ). However, cultured neointimal cells exhibited a strikingly different morphology (Fig. $4 \mathrm{D}$ ). Similar to the results reported by
A

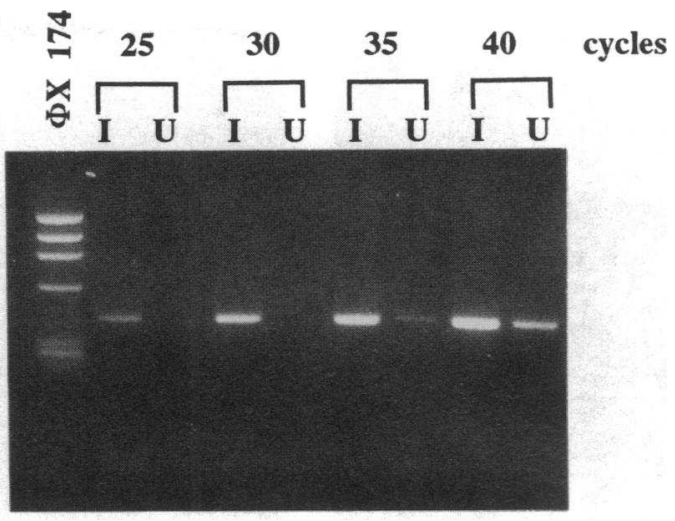

B

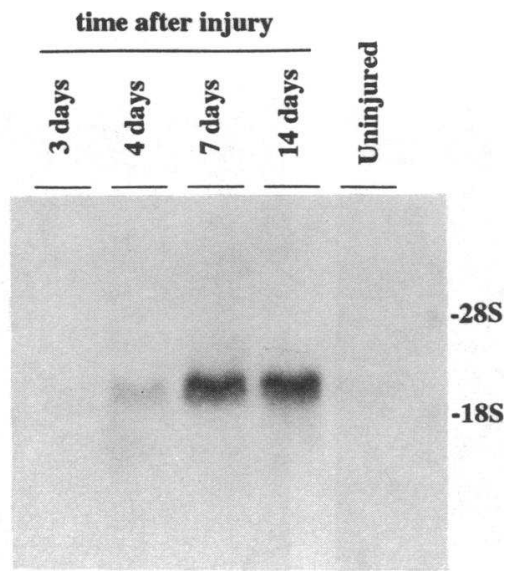

Figure 2. Reexpression of $\mathbf{H} 19$ after vascular injury. Total RNA isolated from control (uninjured) or injured carotid arteries was analyzed by RT-PCR $(A)$ or Northern blotting $(B)$. In $A, 100 \mathrm{ng}$ total RNA isolated from the balloon injured $(I)$ arteries ( 2 wk after injury), or from control, uninjured $(U)$ arteries was reverse transcribed and amplified for $25,30,35$, or 40 cycles and the amplification products analyzed by agarose gel electrophoresis. In $B, 20 \mu \mathrm{g}$ total RNA from arteries injured $3,4,7$, or $14 \mathrm{~d}$ previous or from control, uninjured arteries was analyzed by Northern blotting.

Walker et al. (13), we observed that neointimal smooth muscle cells remained monolayered after confluence and retained a polygonal "epitheliod" morphology. This epitheliod appearance is similar to that observed for neonatal rat (14) and rabbit (10) smooth muscle cells. Both cell cultures were contact inhibited under confluent conditions (data not shown). RNA was harvested from proliferating preconfluent cells, confluent cells, and 3-d postconfluent cells grown in a DSF medium. The RNA was then analyzed by Northern blotting (Fig. 5). H19 mRNA was undetectable in proliferating neointimal cells but a weak signal was observed after the cells reached $100 \%$ confluence. Culturing these neointimal VSMC in a DSF medium for 3 additional $d$ resulted in a dramatic induction of $\mathrm{H} 19 \mathrm{mRNA}$ levels. $\mathrm{H} 19$ was not detectable in the proliferating adult medial VSMC and was only minimally expressed in postconfluent cells in the DSF medium.

\section{Discussion}

This study characterizes the expression of the embryonally expressed gene $\mathrm{H} 19$ in vascular ontogeny and in the vascular 

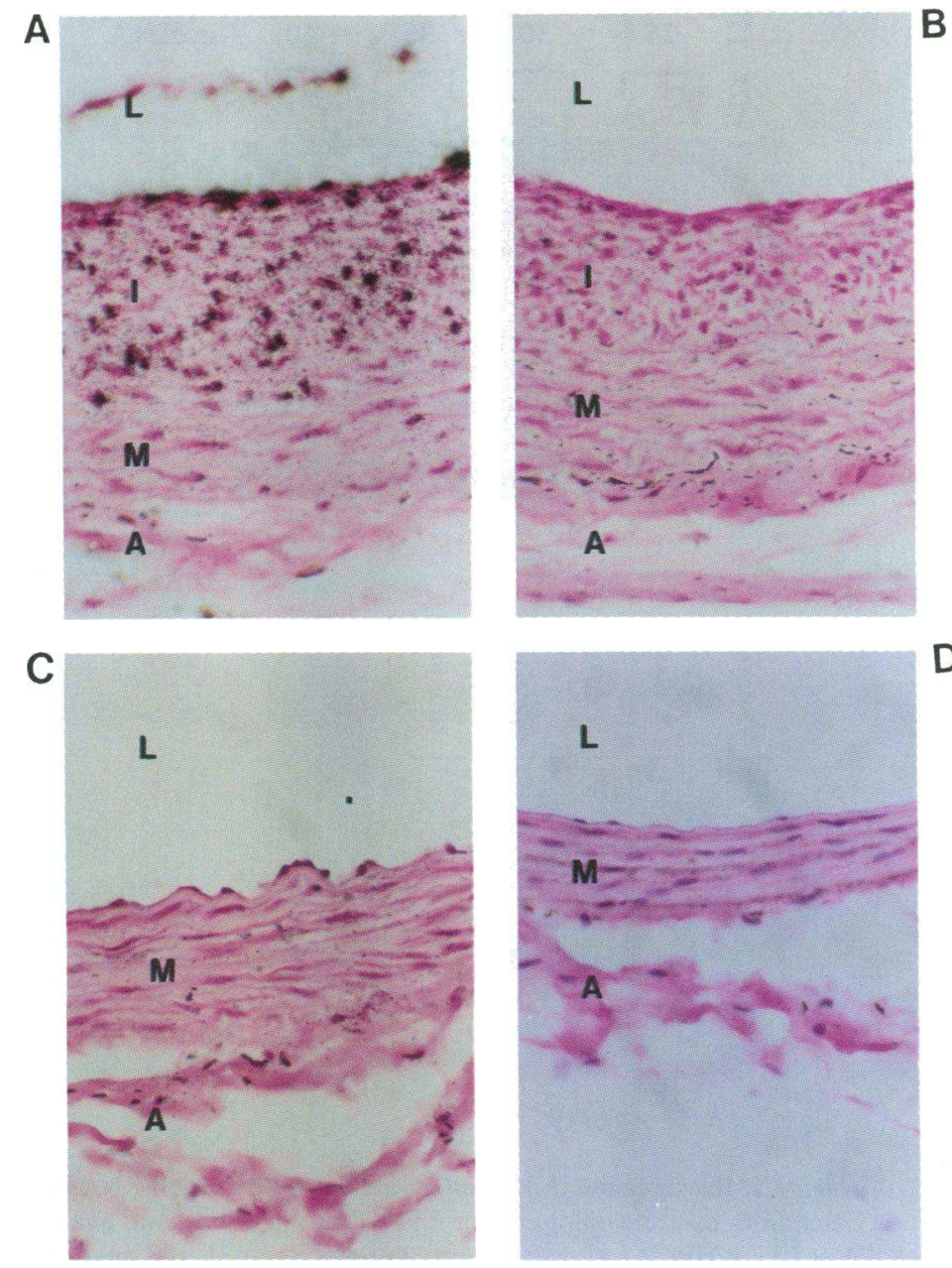

B

D

Figure 3. H19 is expressed predominately in the neointima. Serial sections of injured rat carotid artery hybridized with antisense $\mathrm{H} 19$ complementary RNA probe $(A)$, sense complementary RNA probe $(B)$. Serial sections of uninjured rat carotid artery hybridized with antisense $\mathrm{H} 19$ complementary RNA probe $(C)$, sense complementary RNA probe $(D)$. All sections were stained by hematoxylin and eosin. Original photographed at $\times 400$. $A$, adventitia; $M$, media; $I$, intima; $L$, lumen.
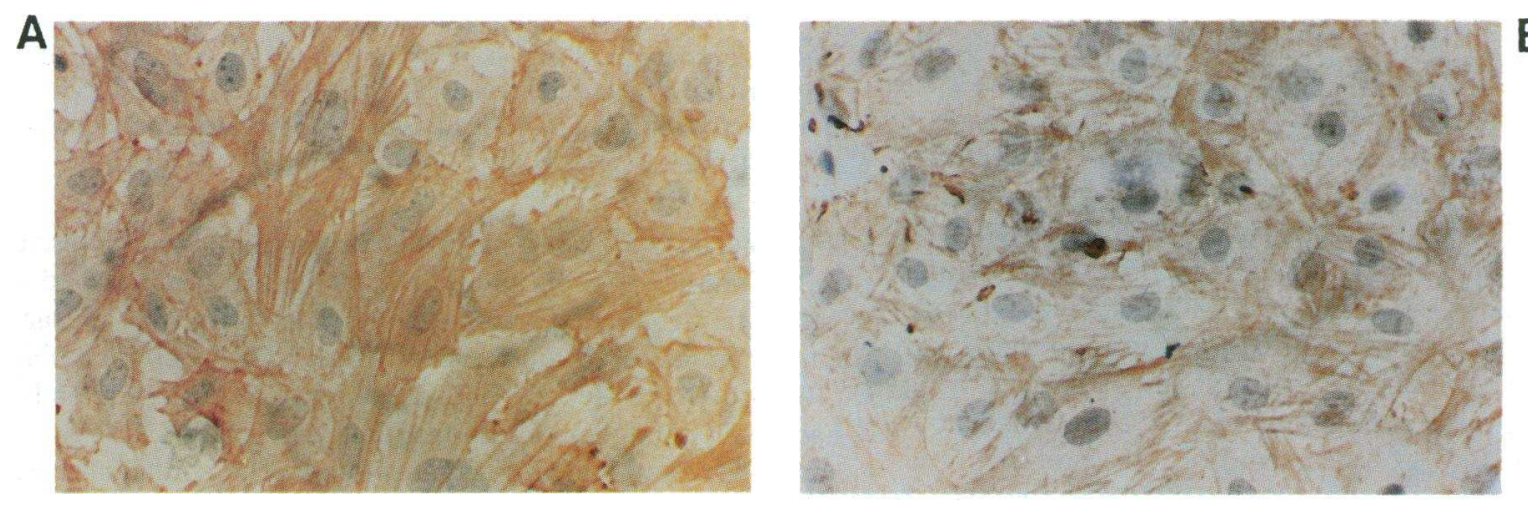

B
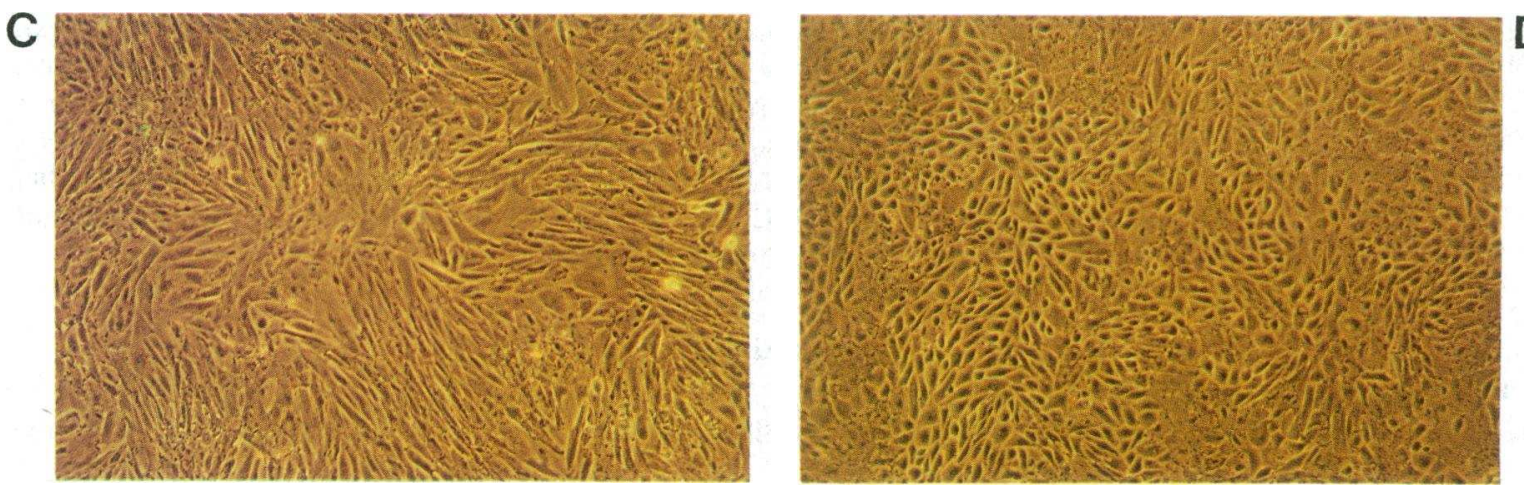

Figure 4. 


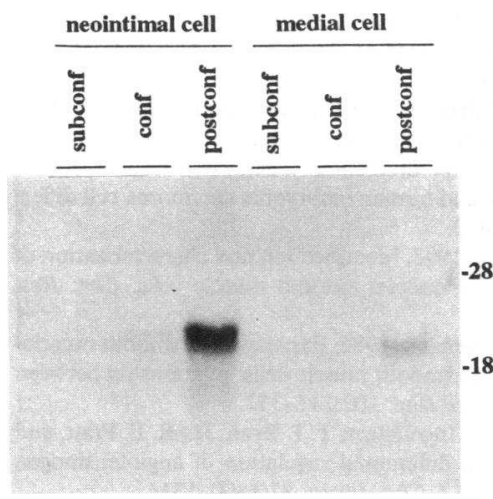

grown in a DSF medium for the last $3 \mathrm{~d}$ (lanes 3,6$)$. The RNA was analyzed by Northern blotting.

response to injury, and attempts to gain insight into its role in vascular smooth muscle growth and differentiation. First, the results indicate that, as in most tissues, the expression of $\mathrm{H} 19$ in the blood vessel decreases dramatically after birth, becoming nearly undetectable in the adult animal. This is in sharp contrast to the expression in other muscle tissues, such as cardiac and skeletal muscle, where the expression of $\mathrm{H} 19$ persists in the adult animal. Secondly, these results support the notion that the vascular response to injury is accompanied by a reexpression of earlier developmental events. Third, we also showed that such phenotypic differences can be maintained in an in vitro culture system and that the expression of $\mathrm{H} 19$ in culture can be regulated.

Restenosis is a significant clinical problem in cardiovascular medicine that limits the long-term success of interventional therapy (e.g., angioplasty) for coronary and peripheral vascular disease $(15,16)$. The restenotic lesion is fibroproliferative in nature and consists of fibroblasts, VSMCs, and macrophage/foam cells $(17,18)$. Among the many animal models for the studies of lesion formation, the balloon-injured rat carotid artery is one of the most widely employed (19, 20-22). The molecular and cellular processes that contribute to the rat lesion formation have been investigated and involve proliferation of "activated" medial VSMCs, migration of the VSMCs into the intima, and further proliferation to form the neointima $(23,24)$. The neointimal VSMCs are phenotypically distinct from the medial VSMCs, since the neointimal cells express a subset of the proteins normally expressed in the embryonic or neonatal VSMCs (2-4). The data are consistent with two distinct hypotheses ( 1$) ;(a)$ outgrowth of dedifferentiated medial VSMC $(2)$ or $(b)$ the presence within the normal media of an undifferentiated stem cell $(25,26)$ that responds to vascular injury with proliferation and migration. However, the differential phenotype of the neointima is not completely "neonatal" (27) nor is it stable. The growing neointimal VSMCs still express certain adult specific characteristics and at later times after injury $(2,28)$, when the rate of growth of the neointima decreases, the expression of the adult phenotype increases.
$\mathrm{H} 19$ was originally cloned in a search for genes that are downregulated after birth. Attempts to use transgenic techniques to investigate the function of this gene have resulted in prenatal lethality at or around day 14 of gestation (8). H19 has been cloned from multiple species and shows a high degree of nucleotide sequence homology, yet no consistent open reading frame has been detected. This observation, plus the location of H19 transcript as part of an abundant cytoplasmic ribonucleoprotein not associated with polysomes, suggests that the gene might function directly at the level of its RNA product (29). In contrast, Leibovitch et al. (30) has reported a human homologue of H19 (ASM) that contains an open reading frame encoding a putative $29-\mathrm{kD}$ protein. Antisera raised against the predicted $\mathrm{COOH}$-terminal region of this protein are reactive against a protein in lysates of human skeletal muscle.

The expression of $\mathrm{H} 19$ in cultured neointimal cells and, to a much lower level, in the medial VSMC, appears tightly coupled to the growth state of the cells. Exponentially growing cells contain little or no $\mathrm{H} 19$ transcript. As the cells approach confluence, the expression of $\mathrm{H} 19$ increases, reaching a maximum $3 \mathrm{~d}$ or more after confluence, when the cells have ceased dividing. Owens and co-workers ( 11 ) have shown that exponentially growing VSMCs exhibit a phenotype different from confluent, quiescent smooth muscle, with the former expressing nonmuscle isoforms of various contractile proteins. After reaching confluence, the expression of these proteins is suppressed while the expression of muscle isoforms is increased, presumably indicating a differentiation process. While the studies by Owens and co-workers (11) were performed with adult aortic smooth muscle cells, it is reasonable to assume a similar event may take place as the neointimal cells become growth arrested. This suggests that the expression of $\mathrm{H} 19$ is a marker for and perhaps a mediator of VSMC differentiation and/or growth arrest. This is consistent with other reports on the expression of H19. For example, Wiles et al. (9) found that the gene is silent in undifferentiated embryonal carcinoma cells and becomes expressed when these cells are induced to differentiate into endoderm. Similarly, in $\mathrm{C} 3 \mathrm{H} 10 \mathrm{~T} 1 / 2$ cells, a multipotential mesodermal embryonic cell line that can mimic different stages in muscle cell development, there was a dramatic increase in $\mathrm{H} 19$ gene expression upon determination of the precursor stem cells to myoblast (6). It should be pointed out that the expression of $\mathrm{H} 19$ is not a universal characteristic of growth-arrested cells. For example, Davis et al. (5) showed that confluent, quiescent Swiss 3T3 cells do not express H19.

The expression and regulation of $\mathrm{H} 19$ in these cultures differs from that reported by Han and Liau (10) for F-31 in rabbit smooth muscle cell cultures. F-31 was not detectable in adult rabbit smooth muscle cells, whereas $\mathrm{H} 19$ was found, albeit at low levels, in postconfluent adult rat smooth muscle cells (Fig. 5). In rabbit neonatal cells, F-31 was observed in proliferating neonatal cells but not in postconfluent cells. In contrast, in the rat neointimal cells, which are phenotypically similar to the neonatal smooth muscle cells $(13,14), \mathrm{H} 19$ was not observed in proliferating cells but became abundant in the

Figure 4. Cultured neointimal and control medial smooth muscle cells are morphologically distinct. Photomicrographs of subconfluent and confluent were examined. Subconfluent control medial $(A)$ and neointimal $(B)$ cells appeared morphologically similar and both cell cultures stained positively for alpha-smooth muscle actin. However, at confluence, control medial smooth muscle cells remained spread and spindleshaped $(C)$, whereas confluent neointimal smooth muscle cells exhibited an epithelioid morphology $(D)$. 
postconfluent cells. These results, plus the different pattern of expression of $\mathrm{H} 19$ and F-31 in adult heart and skeletal muscle, suggests that these two genes are not homologues but may represent distinct genes. However, this point requires further investigation.

Considering $\mathrm{H} 19$ as a marker of VSMC differentiation and perhaps growth arrest, the expression of $\mathrm{H} 19$ in the neointima may suggest that these cells are undergoing differentiation. This is consistent with biochemical and immunocytochemical studies on the expression of contractile and cytoskeletal proteins after vascular injury, which showed an early de-differentiation after injury, followed by a partial re-differentiation (2). Our finding that the expression of $\mathrm{H} 19$ already reached a plateau $7 \mathrm{~d}$ after vascular injury may suggest that the re-differentiation process starts early during the evolution of neointimal formation.

As mentioned above, despite almost a decade of research, the function of $\mathrm{H} 19$ during development and differentiation is still a mystery. While clearly associated with these processes, a causal role, if any, has not been clearly demonstrated. The observation of prenatal lethality as a result of unregulated expression of $\mathrm{H} 19$ in transgenic animals strongly suggests, but does not prove, an important role during development. The present study suggests that studies of $\mathrm{H} 19$ expression in VSMCs may prove useful in defining one of its functions. The declining expression during postnatal development, the re-expression following vascular injury, and the persistent and regulatable expression in cultured neointimal cells constitute an attractive and clinically relevant model system. Precise definition of the function of H19 in VSMC will require both gain- and loss-offunction experiments using VSMCs and biochemical analysis of putatively encoded protein.

\section{Acknowledgments}

We would like to thank Wendy Lee for technical assistance and Melinda Hing for assistance in the preparation of the manuscript.

This work is supported by National Institutes of Health grants HL35610, HL-35252, and HL-42663 and an unrestricted gift from the Bristol-Myers Squibb Fund for Cardiovascular Research.

\section{References}

1. Schwartz, S. M., G. R. Campbell, and J. H. Campbell. 1986. Replication of smooth muscle cells in vascular disease. Circ. Res. 58:427-444.

2. Kocher, O., F. Gabbiani, G. Gabbiani, M. A. Reidy, M. S. Cokay, H Peters, and I. Huttner. 1991. Phenotypic features of smooth muscle cells during the evolution of experimental carotid artery intimal thickening. Biochemical and morphologic studies. Lab. Invest. 66:459-470.

3. Majesky, M. W., C. M. Giachelli, M. A. Reidy, and S. M. Schwartz. 1992. Rat carotid neointimal smooth muscle cells reexpress a developmentally regulated mRNA phenotype during repair of arterial injury. Circ. Res. 71:759-768.

4. Giachelli, C., N. Bae, D. Lombardi, M. Majeski, and S. Schwartz. 1991. Molecular cloning and characterization of $2 \mathrm{~B} 7$, a rat mRNA which distinguishes smooth muscle cell phenotypes in vitro and is identical to osteopontin (secreted phosphoprotein I, 2aR). Biochem. Biophys. Res. Commun. 177:867-873.

5. Davis, R. L., H. Weintraub, and A. B. Lassar. 1987. Expression of a single transfected cDNA converts fibroblasts to myoblasts. Cell. 51:987-1000.

6. Pachnis, V., C. I. Brannan, and S. M. Tilghman. 1988. The structure and expression of a novel gene activated in early mouse embryogenesis. $E M B O$ (Eur. Mol. Biol. Organ.) J. 7:673-681.

7. Poirier, F., C. J. J. Chan, P. M. Timmons, E. J. Robertson, M. J. Evans, and
P. W. J. Rigby. 1991. The murine $\mathrm{H} 19$ gene is activated during embryonic stem cell differentiation in vitro and at the time of implantation in the developing embryo. Development. 113:1105-1114.

8. Brunkow, M. E., and S. M. Tilghman. 1991. Ectopic expression of the H19 gene in mice causes prenatal lethality. Genes Dev. 5:1092-1101.

9. Wiles, M. V. 1988. Isolation of differentially expressed human cDNA clones: similarities between mouse and human embryonal carcinoma cell differentiation. Development. 104:403-413.

10. Han, D. K. M., and G. Liau. 1992. Identification and characterization of developmentally regulated genes in vascular smooth muscle cells. Circ. Res. 71:711-719.

11. Owens, G. K., and L. G. Thomson. 1986. Expression of smooth musclespecific isoactin in cultured vascular smooth muscle cells: relationship between growth and cytodifferentiation. J. Cell Biol. 102:343-352.

12. Naftilan, A. J., W. M. Zuo, J. Ingelfinger, T. J. Ryan, Jr., R. E. Pratt, and V. J. Dzau. 1991. Localization and differential regulation of angiotensinogen mRNA expression in the vessel wall. J. Clin. Invest. 87:1300-1311.

13. Walker, W. M., D. F. Bowen-Pope, R. Ross, and M. A. Reidy. 1986 Production of platelet-derived growth factor-like molecules by cultured arteria smooth muscle cells accompanies proliferation after arterial injury. Proc. Natl. Acad. Sci. USA. 83:7311-7315.

14. Majesky, M. W., E. P. Benditt, and S. M. Schwartz. 1988. Expression and developmental control of platelet-derived growth factor A-chain and B-chain/Sis genes in rat aortic smooth muscle cells. Proc. Natl. Acad. Sci. USA. 85:1524 1528.

15. Leimgruber, P. P., G. S. Roubin, J. Hollmann, G. A. Cotsonis, J. S. Douglas, S. B. King, and A. R. Gruentzig. 1986. Restenosis after successful coronary angioplasty in patients with single vessel disease. Circulation. 73:710-717.

16. Roubin, G. S., S. B. King III, and J. S. Douglas, Jr. 1987. Restenosis after percutaneous transluminal coronary angioplasty: Emory University Hospital experience. Am. J. Cardiol. 60:39B-43B.

17. Waller, B. F., H. J. Gorfinkel, F. J. Rogers, K. M. Kent, and W. C. Robert. 1984. Early and late morphologic changes in major epicardial coronary arteries after percutaneous transluminal coronary angioplasty. Am. J. Cardiol. 53:42C$47 \mathrm{C}$.

18. Liu, M. W., G. S. Robins, and S. B. King III. 1989. Restenosis after coronary angioplasty. Potential biologic determinants and role of intimal hyperplasia. Circulation. 79:1374-1387.

19. Fishman, J., G. Ryan, and M. Karnovsky. 1975. Endothelial regeneration in the rat carotid artery and the significance of endothelial denudation in the pathogenesis of myointimal thickening. Lab. Invest. 32:339-351.

20. Guyton, J., R. Rosenburg, A. Clowes, and M. Karnovsky. 1980. Inhibition of rat arterial smooth muscle cell proliferation by heparin. In vivo studies with anticoagulant and nonanticoagulant heparin. Circ. Res. 46:625-634.

21. Clowes, A. W., M. A. Reidy, and M. M. Clowes. 1983. Kinetics of cellular proliferation after injury: I. Smooth muscle growth in the absence of endothelium. Lab. Invest. 49:327-333.

22. Fingerle, J., R. Johnson, A. Clowes, M. Majesky, and M. Reidy. 1989. Role of platelets in smooth muscle cell proliferation and migration after vascular injury in the rat carotid artery. Proc. Natl. Acad. Sci. USA. 86:8412-8416.

23. Goldberg, I. D., M. B. Stemerman, B. J. Ransil, and R. L. Fuhno. 1980. In vivo aortic muscle cell kinetics. Differences between thoracic and abdominal segments after intimal injury in the rabbit. Circ. Res. 47:182-189.

24. Hanke, H., T. Strohschneider, M. Oberhoff, E. Betz, and K. R. Karsch. 1990. Time course of smooth muscle cell proliferation in the intima and media of arteries following experimental angioplasty. Circ. Res. 67:651-659.

25. Benditt, E. P., and J. M. Benditt. 1973. Evidence for a monoclonal origin of human atherosclerotic plaques. Proc. Natl. Acad. Sci. USA. 70:1753-1756.

26. Zanellato, A. M. C., A. C. Borrione, M. Tonello, G. Scannapieco, P. Pauletto, and S. Sartore. 1990. Myosin isoform expression and smooth muscle cell heterogeneity in normal and atherosclerotic rabbit aorta. Arteriosclerosis. 10:996-1009.

27. Kocher, O., O. Skalli, D. Cerutti, F. Gabbiani, and G. Gabbiani. 1985 Cytoskeletal features of rat aortic cells during development: An electron microscopic, immunochemical, and biochemical study. Circ. Res. 56:829-838.

28. Grunwald, J., J. Fingerie, H. Hammerie, E. Betz, and C. C. Handenschild. 1987. Cytocontractile structures and proteins of smooth muscle cells during the formation of experimental lesions. Exp. Mol. Pathol. 46:78-88.

29. Brennan, C. I., E. C. Dees, R. S. Ingram, and S. M. Tilghman. 1990. The product of the $\mathrm{H} 19$ gene may function as an RNA. Mol. Cell. Biol. 10:28-36.

30. Leibovitch, M. P., V. C. Nguyen, M. S. Gross, B. Solhonne, S. A. Beibovitch, and A. Bernheim. 1991. The human ASM (adult skeletal muscle) gene: expression and chromosomal assignment to $11 \mathrm{p} 15$. Biochem. Biophys. Res. Commun. 180:1241-1250. 